\title{
Reconsidering the Training of Famous Teachers in Military Academies
}

\author{
Yao Miao ${ }^{1, \mathrm{a}}$
}

Special Police Academy of the Armed Police Force

940466022@qq.com

\begin{abstract}
The training of famous teachers is an important measure for military colleges and universities to strengthen the construction of the teaching team, improve the competitiveness and influence of the teaching team, and promote the overall development of military ed.ucation. The training of famous teachers in military colleges and universities should combine external experts with internal talents, independent development with policy support, evaluation and selection with strict management, material support with spiritual incentive.
\end{abstract}

Keywords: Teacher training, Military academies, Talent team

\section{关于军队院校名师培养的再思考}

\author{
姚沝 1 , a
}

武警部队特警学院

940466022@qq.com

\begin{abstract}
摘要:
名师培养是军队院校全力加强教师队伍建设, 提高教师队伍竞争力和影响力, 推进军事教育全面发展 的重要举措。军队院校名师培养应实行外引专家与内育人才相结合、自主发展与政策扶持相结合、评 审选拔与严格管理相结合、物质保障与精神激励相结合。
\end{abstract}

关键词: 名师培养; 军队院校；人才队伍；

\section{1. 前言}

习主席强调指出“人才强则事业强, 人才兴则军队 兴”, 要贯彻落实习主席重要指示, 构建“三位一体” 新型军事人才培养体系, 为实现党在新时代的强军目 标提供人才智力支撑, 军队院校就必须围绕强军目标, 大力加强教师人才队伍建设。名师作为有重大贡献和 影响力的优秀教师, 无疑是军队院校的品牌, 是军队 院校最为宝贵的人才资源。为此, 军队院校必须将名 师培养作为关系军事教育全局的战略工程来抓，抓出 力度、抓出成效, 努力选拔、培养、造就一批能够发 挥示范引领作用的高水平教师, 全面提升教师队伍的 素质能力, 不断提高军队院校的办学水平。

\section{2. 军队院校名师培养的重要意义}

\section{1 发挥人才磁场效应, 带动教师队伍全面发 展。}

学高为师、身正为范, 名师代表着军队院校的办 学水平和品牌声誉, 对教师队伍具有巨大的影响力和 号召力。实践证明: 一名名师往往能够带动一个专业, 带动一支团队，产生一花香来百花开的效用。放眼中 外名校, 名师群体往往发挥着巨大的磁场效应, 他们 一般具有较强的改革创新和团结协作精神, 也具备组 织带领专业梯队科研攻关的突出能力。为此, 国内各 个院校也纷纷强化名师培养力度, 不断壮大名师后备 梯队。军队院校在教师队伍素质能力参差不齐的情况 下，更需要发挥名师人才磁场的凝聚带动作用，从而 推进教师队伍素质能力的整体提高。

\section{2 迈实内涵发展道路, 提升军队院校办学水 平。}

军队编制体制调整改革以来，军队院校构建“三位 一体”新型军事人才培养体系，由过去一味扩张规模 的外延式发展道路迈上数量规模适度、体系结构优化 的内涵式发展道路, 办学条件明显得到改善。目前军 队院校面临的主要矛盾聚焦于如何把握内涵发展的核 心要义, 不断提高办学水平上。我们认为, 内涵发展 
的核心要义就在于改进办学指导思想和管理理念，加 强师资队伍和专业学科建设, 从而立足“两个面向”, 不断推动军队院校的全面建设。军队院校名师培养的 本质和目标即为打造一支高水平的师资队伍，为内涵 式发展提供坚实的人才智力支撑, 特别是在当前军队 院校教育教学转型的关键时刻, 这一点就显得尤为重 要。

\section{3 改变重研轻教现象,归正教学办学中心地} 位。

围绕强军目标, 军队院校的办学定位必须立足于 以为军队培养新型军事人才为中心。但是, 近些年来, 部分军队院校出现了重科研轻教学的现象, 教学的办 学中心地位不够突出。不言而喻, 科研确实是军队院 校教师的重要职责, 然而, 对部分教师而言, 科研成 果可以带来“名利双收”，教学工作则费力不讨好，在 职称评定中难以发挥关键性作用，导致部分教师对教 学不愿倾力付出, 甚至少数专业造诣很深的教师对教 学也有所忽视。为了从根本上改变这种现象, 提升军 队院校的教学质量, 有必要大力实施名师战略工程, 以名师培养工作为抓手，在军队院校中营造一切为了 教学, 一切服务教学的良好氛围, 这对于归正教学中 心地位, 高质量培养新型军事人才有着十分重要的现 实意义。

\section{3. 军队院校名师培养的策略分析}

军校老师是不断推动高等军事教育事业蓬勃发展 的重要力量, 是办好使广大人民群众满意的高等军事 教育的主力军。而名师并非自生、自长、自封的，他 源自于广大教师的不解奋斗, 更源自于军队院校的培 养塑造, 需要军队院校围绕新时期强军目标, 超前谋 划、科学施策、精心组织、严格考评, 努力建立名师 培养的长效机制, 才能切实增强名师培养的实效性, 让名师与名校相得益彰, 共运生辉。

\section{1 外引专家与内育人才相结合。}

没有名师就没有名校, 先有名师而后有名校。一 方面, 军队院校要加大人才引进力度。确立高层次人 才“不求所有, 但求所用, 更求有为” 的指导思想, 采 取从地方特招入伍、兄弟单位选调、外聘客座教授等 多种办法, 延揽军地知名专家、科研人员来军队院校 参加教研工作。充分引用社会资源, 广泛聘请地方政 府、机关、高校知名专家、学者和教授补充教员队伍, 承担相关教学任务, 弥补现任教师数量和质量的不足。 同时, 军队院校要搭建各类学术交流平台, 加强与军 地协作单位、著名学者的学术交流活动, 定期延请专 家学者来院讲学指导或访问交流, 吸引高层次人才参
与学术科研活动, 以开明开放的姿态促进学术争鸣, 提升办学层次。另一方面, 军队院校要加强名师的内 部培养。军队院校是名师培养的摇篮, 但名师的成长 绝非一朝一夕之功，通常经历“三年打基础，六年成骨 干, 九年出名师”的成长周期, 需要有意识、有规划、 有目的地组建成才梯队, 厚植后备力量。为此, 名师 成才梯队可以依据人才成长规律划分为合格教师、骨 干教师、优秀教师、名师四个阶段和梯次，为教师搭 建成才的阶梯，明确努力的方向。为让名师尽快脱颖 而出, 军队院校要重点培养潜力巨大的优秀教师, 以 创建精品课程为切入点, 督促他们围绕实战化教学改 革改进教学思路、优化教学方法、提高教学能力; 以“双 重” 建设和军队重大课题研究为牵引, 加大帮带指导 与资金扶持力度，促使他们多出成果、出好成果，大 幅提高学术造诣与科研能力 [1]。

\section{2 自主发展与政策扶持相结合。}

名师培养的最终落脚点, 在于教师各自专业的自 主发展上, 教师必须坚持不解地提升素质能力和专业 水平, 才能逐步成长为名师。为促进教师的自主发展, 一要加强思想教育。引导教师树立革命军人核心价值 观与远大的专业发展理想, 能够立得住岗位, 而得住 衰寞, 全身心投入到教育教学事业中来; 二要端正教 研方向。引导教师及时关注世界新军事变革发展动向, 关注军队最新理论研究成果, 关注院校教育发展和教 学改革趋势，立足“两个面向”提高专业水平; 三要培 养名师风格。成为名家大家, 既要兼收并蓄, 取各家 之长, 也要善于创造创新, 成一家之言, 要引导教师 创造适合自己个性特点的教学方法和研究模式, 教学 与研究都能充分突出人文性、追求艺木性、实现高效 性, 逐步树立名师品牌, 锻造大家风范。同时, 我们 也要认识到: 政策环境是名师培养的重要条件, 教师 能否成长为名师, 主要靠自身努力, 但也离不开政策 的支持与保障。一要确立名师培养规范。尽快出台和 完善高层次人才引进制度、名师评审考核制度、名师 表彰奖励制度等系列规章制度，建立职务晋升、职级 考评、绩效待遇等长效机制，为名师培养打开政策“绿 色通道” ; 二要实行赴部队调研和岗位代职机制。将 教师赴部队调研和代职计划列入军队院校党委议事日 程, 超前谋划, 精心组织, 有序开展相关工作, 并与 总部机关主动协调, 积极参与部队重大演习、处置大 规模突发事件等多样化任务, 提高“教为战、研为战” 的实践素质能力; 三要搭建交流学习平台。通过定期 组织名师讲堂、名师对话等教学公开活动, 培养名师 意识、打造名师品牌, 积极推荐名师参加国家、军队 的重大学术科研活动, 厚植名师底蕴、展示名师风采。 定期选派优秀教师赴国内外知名院校交流访问和学习 进修, 拓宽学术研究视野, 培养战略思维能力 [2]。 


\section{3 物质保障与精神激励相结合。}

强化名师培养, 物质保障与精神激励缺一不可。 为尽快推出名师大家，军队院校应在人力、财力、物 力等方面加大投入力度。要创设名师培养专项基金。 结合“双重工程” 建设, 为重大教学科研项目、重要培 训研修或学术交流、出版有影响力的学术课题与专著 等提供足够财力支撑; 同时, 要创造名师培养条件。提 供完善的办公场所和良好的工作环境, 配备必要的办 公设备, 积极主动照顾、解决生活上的问题与困难, 为名师培养解除后顾之忧。在物质保障的同时也要重 视精神激励。激励理论认为: 就激励的效果而言, 物 质的获得是浅显的、短暂的, 而精神的获得则是深层 的、持久的。作为知识分子群体, 教师特别是优秀教 师有着较强的事业心和荣誉感, 他们敏而好学, 要求 进步, 更加重视精神层面的追求。因此, 军队院校在 重视物质激励的同时, 更要致力于激发职业自豪感、 责任感和使命感。一要加强與论宣传。通过宣传名师 先进事迹、教研成果、教育理念、成长轨迹等, 提高 名师知名度和社会地位, 引导广大教师亲其师、信其 道, 让名师真正成为鲜明旗帜; 二要给于充分肯定。 对名师取得的成绩给予重点奖励, 特别是取得重大成 果的名师, 在评选军队育才奖、进入高层次专业技术人 才以及提前晋职等方面应当予以优先考虑; 三要因才 放手重用。对名师, 特别是名师培养对象要放手让他 们挑大梁、做大事, 同时积极发挥他们在党委决策和 院校建设中的咨询、指导作用, 充分调动爱岗敬业、 奋发有为的积极性和创造性。实践证明：只有广大员 工都享有公平的机制、公平的环境、公平的条件和公 平的发展机会, 才能有效激发活力和潜能, 使大家各 尽其能、各得其所而又和谐相处。

\section{4 评审选拔与严格管理相结合。}

名师培养重在评审选拔, 贵在严格管理。一方面, 要在把握名师内涵与素质结构的基础上, 明确选拔标 准, 规范评审程序, 坚决杜绝迁就照顾与论资排辈, 真正做到能者上、庸者下, 依比例、依制度、依条件 逐级公平竞争、逐级严格遴选, 做到评审过程公开化、 评审程序标准化、评审结果权威化, 让名师名至实归、 脱颖而出。另一方面, 要对名师的考核评估实施严格 管理。要建立完善名师档案, 把教学工作、科研学术、 师德师范、重大贡献等情况进行全面量化评估, 作为 岗位选配、职级晋升、绩效挡位的重要依据。对已经 评审出的名师要打破终身制, 实行三年一聘任、五年 一评选, 定期对名师的师德表现、业务技能、效能发 挥等各方面进行全面系统的考核, 按绩排序, 排序 靠后的给予黄牌警告, 连续两次黄牌的即为自动淘汰。 业务部门要及时跟踪掌握名师的学习交流、教学科研、 资金使用等情况，在任期内如果有违背师德风范或不 履行义务的行为, 应当取消名师资格与荣誉 [3]。

\section{4. 总结}

基于以上现状和存在的问题, 我们要高度重视军 队院校名师队伍的建设工作, 充分理解和把握习主席 军队人才建设重要论述, 坚决贯彻落实军队院校建设 战略方针, 围绕强军目标, 立足两个面向, 根据军队 院校办学需求和实际情况对军队院校名师队伍建设加 以严格规范和科学引导, 让名师队伍人才资源真正成 为军队院校建设的助推器。为此, 首先要把名师队伍 建设放在满足军事斗争需要, 为部队建设培养一流军 事人才的高度来对待, 只有具备了名师人才方阵, 才 极有可能培养出能力素质优秀的学生来, 才能打赢未 来的战争。其次, 只有站在发展的角度, 以系统开放 的理论认识高度探究人才培养规律, 才能理解名师队 伍建设的现实意义, 才能把握军队院校名师培养的必 要性和紧迫性, 为名师培养拿出一套切实可行的对策 来。最后, 名师培养是一个系统工程, 绝非一朝一夕 之功, 必须依靠各级下长功, 使实劲, 本着对军队, 对学员高度负责的态度, 科学决策, 合理计划, 统筹 协调, 严格管理, 将名师培养作为关系军队院校长远 发展的战略工程来抓, 就一定能抓出成果, 抓出实效, 让军队院校涌现出一大批具有良好职业道德素养, 优 秀专业技能, 丰富文化底蕴, 突出教研能力的名师队 伍来。

\section{References}

[1]Shen Qiuhu,Wang Xiaojie,Wang Liqiang,Li Xiaojing.The problem analysis and countermeasure research of the military service education[J].Education and teaching forum,2019(51):231-232.

[2] Wang Dan, Lu Yang, Sun Mingmei. Research on Construction of Information Quality Education System in MilitaryColleges[J].Intelligence exploration,2019(09):28-32.

[3] Wu Guoqing. The Significance of Strengthening Military Forces in Military Academy Education in the New Era[J]. The road to success,2019(18):5-6. 